\title{
Presence of oestradiol-17 $\beta$ in the rabbit ovum and its investments
}

\author{
P. E. Lindahl, J. Örberg*, S. Torsberg $\dagger$ and P. Sjöblom \\ Institute of Zoophysiology, University of Uppsala, Box 560, S-751 22 Uppsala, and \\ *Institute of Animal Physiology, Agricultural College, Uppsala, Sweden
}

\begin{abstract}
Summary. Untreated rabbit eggs contained 1-2 pg oestradiol-17 $\beta /$ egg. Treatment with hyaluronidase for $20 \mathrm{~min}$, but not for $10-13 \mathrm{~min}$, removed the cumulus and corona cells and all oestradiol.
\end{abstract}

\section{Introduction}

In the presence of $\mathrm{Mg}^{2+}$ or $\mathrm{Ca}^{2+}$, ATP induces association between acrosomal regions of bovine spermatozoa (Lindahl, 1968). The reaction leading to the adhesive properties of the cell membrane required for this so-called 'head-to-head' association is also initiated by other triphosphate nucleotides, e.g. ITP, GTP, UTP and CTP (Lindahl, 1974). Oestradiol- $17 \beta\left(5 \times 10^{-7} \mathrm{M}\right)$ can also produce the same effect (Lindahl, 1978). This hormone is present in the follicular fluid (see Steinetz, 1973) and could therefore be taken up by the ovum and its investments to act as a natural trigger for the adherence reaction between the sperm head and the outer surface of the egg investment. The aim of the present experiments was to determine whether this hormone is present in the rabbit ovum and/or its investments.

\section{Materials and Methods}

Nine fertile rabbit does of mixed breed were treated twice daily with subcutaneous injections of 25 i.u. FSH (Sigma, U.S.A.) for 3 consecutive days. Superovulation was induced by intravenous injection of 75 i.u. hCG (Organon, The Netherlands) and the rabbits were killed about $16 \mathrm{~h}$ later. The oviducts were excised and the eggs were washed out with $5 \mathrm{ml} \mathrm{Krebs-Ringer} \mathrm{solution} \mathrm{(Cohen,} \mathrm{1959),}$ modified by exclusion of $\mathrm{CaCl}_{2}$ : this modified medium was used throughout. The eggs were transferred with a few $\mu$ l of this fluid into $1.0 \mathrm{ml}$ fresh Krebs-Ringer solution, frozen and stored at $-18^{\circ} \mathrm{C}$ until analysed. Those from Rabbit 1 were not treated. As much of the cumulus as possible was dissected away from the eggs of Rabbit 2 by means of glass needles. The eggs of Rabbit 6 were already free from cumulus and other follicular cells when collected. The eggs from the remaining does were treated with about 150 i.u. hyaluronidase (Sigma, Type II)/ml Krebs-Ringer as described by Fraser, Dandekar \& Vaidya (1971) for about $20 \mathrm{~min}$ (Nos 3 and 4) and 10-13 min (Nos 5, 7, 8 and 9). The cumulus cells were removed by stirring the solution during treatment. The eggs were then transferred to $1.0 \mathrm{ml} \mathrm{Krebs-Rirger} \mathrm{solution} \mathrm{(changed} \mathrm{once} \mathrm{for} \mathrm{the} \mathrm{eggs} \mathrm{from} \mathrm{Nos} 3,4$ and 5), and the corona radiata cells were dispersed from the zona by shaking. Longer mechanical treatment was required to remove all the cells from eggs subjected to shorter treatment with hyaluronidase. Cellular removal was verified for all eggs by microscopic examination.

Before analysis for oestradiol or oestrone, the samples were thawed and homogenized. The homogenates were extracted with ethyl ether which was then evaporated and the residues taken to analysis. The oestradiol- $17 \beta$ was determined, without chromatography steps, by radioimmunoassay with an antibody against oestradiol- $17 \beta$ raised in sheep. Cross-reactivities were $11.1 \%$ with oestrone, $0.7 \%$ with oestradiol- $17 \alpha$ and $0.6 \%$ with oestriol. The labelled steroid used was $\left[2,4,6,7,16,17-{ }^{3} \mathrm{H}(\mathrm{N})\right]-$ oestradiol-17 $\beta$ (sp. act. $138 \mathrm{Ci} / \mathrm{nmol}$ : New England Nuclear, Boston, U.S.A.). Uncontaminated modified Krebs-Ringer was used for blank determinations and in all cases the recorded blank values 
were below the limit of detection $(5 \mathrm{pg})$. Because of the comparatively great cross-reactivity with oestrone, the content of this hormone was also determined, in eggs untreated with hyaluronidase, by immunoassay with a highly specific antibody against oestrone raised in sheep. The cross-reactivity of this antibody was $0.44 \%$ with oestradiol- $17 \beta$ and $<0.1 \%$ with oestriol. The labelled compound was [2,4,6,7-3 $\mathrm{H}]$ oestrone (sp. act. $98 \cdot 5 \mathrm{Ci} / \mathrm{nmol}$ : New England Nuclear).

\section{Results}

It can be seen from Table 1 that the ovum and its investments (Rabbit 1 ) contain a significant amount of oestradiol-17 $\beta$. From the figures for mean content of oestrone $(0 \cdot 8 \mathrm{pg} / \mathrm{egg}$ : Table 2$)$ and oestradiol$17 \beta$, both per untreated egg, and cross-reactivity with oestrone, the relative contribution of oestrone to the recorded value of oestradiol-17 $\beta$ can be calculated as $(11 \cdot 1 \times 0.8) /(1.9 \times 100)$, i.e. about $5 \%$ and below the limit of accuracy of the method. The eggs from Rabbit 2 showed an unexpectedly low value with respect to the amount of material removed from these eggs. Hyaluronidase treatment lasting $20 \mathrm{~min}$ (Rabbit 3 ) gave very striking effects: the cumulus and corona cells were easily removed and the remaining ova plus zonae pellucidae did not contain any oestradiol-17ß. Treatment with hyaluronidase for 10-13 min (Rabbits 5, 7, 8 and 9) re noved the cumulus and corona cells but left a comparatively large amount of oestradiol-17 $\beta$ in the remaining ova + zonae pellucidae, which was well in keeping with the result obtained from the eggs of Rabbit 6 , i.e. when only the zona was present on the collected eggs. The 5 eggs of Rabbit 4 were analysed inadvertently with those of Nos 5, 7, 8, and 9 and this oestrogen value was therefore probably a little lower than it would otherwise have been.

Table 1. The numbers of eggs collected and analysed from each doe, treatment of the eggs, the state of their investments at analysis, and the amounts of oestradiol- $17 \beta$ found

\begin{tabular}{|c|c|c|c|c|c|}
\hline \multirow[b]{2}{*}{ Rabbit } & \multirow{2}{*}{$\begin{array}{l}\text { No. of eggs } \\
\text { analysed }\end{array}$} & \multirow{2}{*}{$\begin{array}{l}\text { Treatment } \\
\text { of eggs }\end{array}$} & \multirow{2}{*}{$\begin{array}{c}\text { State of } \\
\text { investments }\end{array}$} & \multicolumn{2}{|c|}{$\begin{array}{c}\text { Amount of oestradiol- } \\
17 \beta(\mathrm{pg})\end{array}$} \\
\hline & & & & Total & Per egg \\
\hline 1 & 10 & None & Complete & $20 \cdot 0$ & $2 \cdot 0$ \\
\hline 2 & 20 & $\begin{array}{l}\text { Cumulus dissected } \\
\text { with glass needles }\end{array}$ & $\begin{array}{l}\text { Cumulus and corona } \\
\text { partly removed }\end{array}$ & $22 \cdot 0$ & $1 \cdot 1$ \\
\hline 3 & 43 & $\begin{array}{l}\text { Hyaluronidase ( } 20 \\
\text { min) }\end{array}$ & $\begin{array}{l}\text { Zona pellucida } \\
\text { only }\end{array}$ & N.D. & N.D. \\
\hline 6 & 12 & None & Zona pellucida only & $14 \cdot 0$ & 1.8 \\
\hline $4^{*}$ & 5 & $\begin{array}{l}\text { Hyaluronidase ( } 20 \\
\text { min) }\end{array}$ & & & \\
\hline $\begin{array}{l}5 \\
7\end{array}$ & $\left.\begin{array}{r}10 \\
6\end{array}\right)$ & Hyaluronidase (10- & Zona pellucida only & $63 \cdot 0$ & 1.6 \\
\hline 8 & $12\}$ & $13 \mathrm{~min}$ ) & & & \\
\hline 9 & 7) & & & & \\
\hline
\end{tabular}

N.D. not detectable.

* See text.

Table 2. The oestrone content of eggs from two does

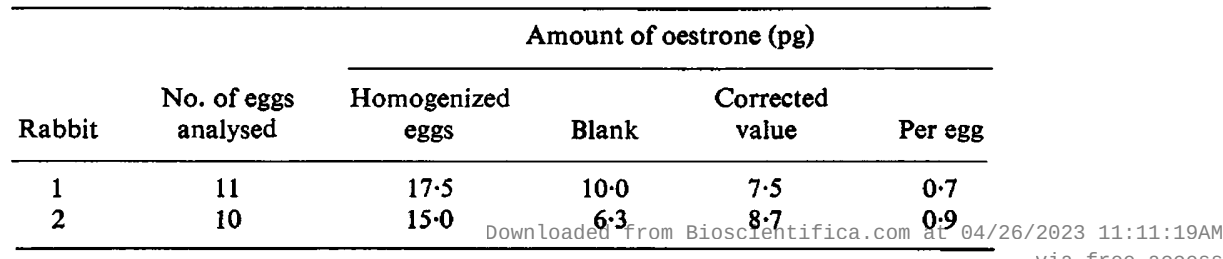




\section{Discussion}

Our results are compatible with the conception that oestradiol-17 $\beta$ is present in the material, of which hyaluronic acid is a constituent, which cements the cumulus and corona cells together and to the zona pellucida. The occurrence of oestradiol-17 $\beta$ in mammalian eggs has not, to our knowledge, previously been established, but its presence has been reported in eggs of the teleost fish, Gadus callarias (Gottfried, Hunt, Simpson \& Wright, 1962).

Fraser et al. (1971) have demonstrated that no significant change in fertilization rate occurs when rabbit eggs are treated with hyaluronidase to remove the cumulus and corona cells. This treatment does not necessarily also remove the oestradiol- $17 \beta$ present at the zona, and so this hormone could be the factor which triggers the process leading to the adhesive properties of the acrosomal region of the spermatozoon at fertilization.

The antisera against oestradiol-17 $\beta$ and oestrone were gifts from Dr K. Martinsson and Dr L. E. Edquist, Royal Veterinary College, Uppsala, Sweden. The analysis of oestrone was performed by staff of the Primate Laboratory for Reproduction Research, University of Uppsala.

\section{References}

COHEN, P.P. (1959) Suspending media. In Manometric Techniques, 2nd edn, pp. 147-150. Eds W. W. Umbreit, R. H. Burres, \& E. F. Stauffer. Burgess Publishing Co, Minneapolis.

Fraser, L.R., DANDEKaR, P.V. \& VAIDYA, R.A. (1971) In vitro fertilization of tubal rabbit ova partially or totally denuded of follicular cells. Biol. Reprod. 4, 229-233.

GotTFRIEd, H., Hunt, S.V., Simpson, T.H. \& WRIGHT, R.S. (1962) Sex hormones in fish. The oestrogens of cod (Gadus callarias). J. Endocr. 24, 425-430.

LINDAKL, P.E. (1968) Structural changes in the apical membrane of the bull spermatozoon. I. The effect of ATP and its inhibition. Expl Cell Res. 53, 626-638.
LINDAHL, P.E. (1974) Nucleotide specificity of the "ATP-dependent" surface reaction of the acrosomal region of the bull sperm head. Expl Cell Res. 86, 47-54.

LINDAHL, P.E (1978) Effects of some steroid hormones on head-to-head association in bovine spermatozoa. Expl Cell Res. (in press).

STEINETZ, B.G. (1973) Secretion and function of ovarian estrogens. In Handbook of Physiology, Section 7: Endocrinology, Vol. II, Female Reproductive System, Part 1, pp. 439-466. Eds R. O. Greep \& E. B. Astwood. Am Physiol. Soc., Washington, D.C.

Received 30 May 1977 